\title{
JOSÉ SPANIOL
}

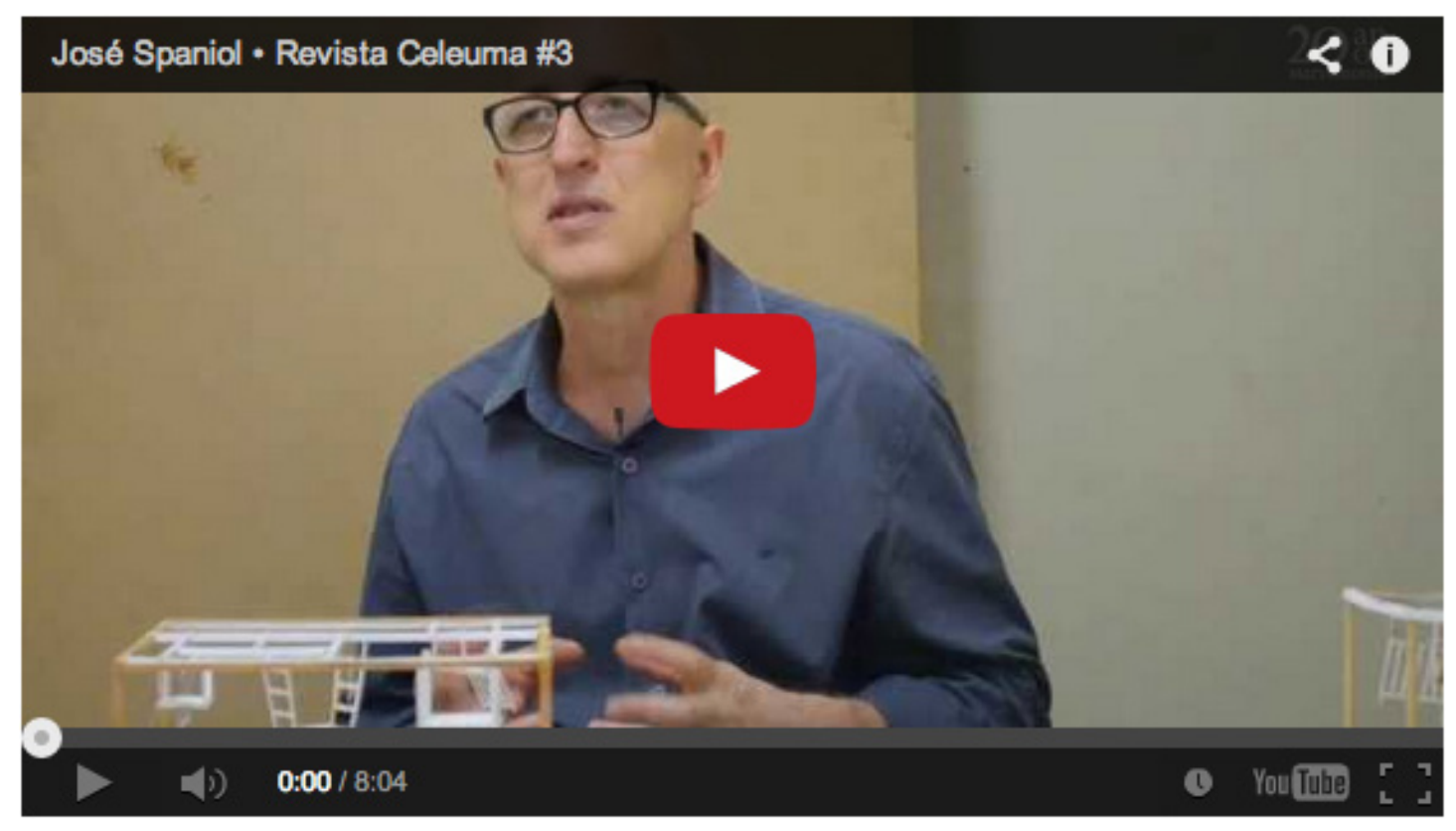

